\title{
STUDIES OF BRAZILIAN METEORITES. II. THE AVANHANDAVA CHONDRITE: MINERALOGY, PETROLOGY AND CHEMISTRY
}

\author{
W. PAAR*, K. KEIL, G. B. GOMES**,
}

Department of Geology and Institute of Meteoritics, University of New Mexico, Albuquerque, New Mexico 87131, USA

\section{and \\ E. JAROSEWICH}

Department of Mineral Sciences, Smithsonian Institution, National Museum of Natural History, Washington, D.C. 20560, USA

ABSTRACT A description of the Avanhandava, State of Sao Paulo, Brazil, meteorite, which fell in 1952, is given using optical, microprobe, and bulk chemical data. This H-group or olivine-bronzite chondrite contains olivine $\left(\mathrm{Fa}_{17.3}\right)$, bronzite $\left(\mathrm{Fs}_{16.5}\right)$, diopside $\left(\mathrm{Wo}_{45.3} \mathrm{En}_{49.0} \mathrm{Fs}_{5.7}\right)$, oligoclase $\left(\mathrm{Or}_{5.4} \mathrm{Ab}_{84.1} \mathrm{An}_{10.4}\right)$, whitlockite, chlorapatite, kamacite, taenite (plessite), troilite, chromite, native copper, pentlandite, ilmenite, bravoite, mackinawite, and chalcopyrrhotite. On the basis of mineral and bulk compositions as well as its texture, the Avanhandava meteorite is classified as an $\mathrm{H} 4$ chondrite.

RESUMO Dados ópticos e químicos são fornecidos para o meteorito de Avanhandava, Estado de São Paulo, Brasil, cuja queda teve lugar em 1952. Este olivina-bronzita condrito, pertencente ao grupo $\mathrm{H}$, consiste em olivina $\left(\mathrm{Fa}_{17,3}\right)$, bronzita $\left(\mathrm{Fs}_{16,5}\right)$, diopsídio $\left(\mathrm{Wo}_{45,3} \operatorname{En}_{49,0} \mathrm{~F}_{5_{5,7}}\right)$, oligoclásio $\left(\mathrm{Or}_{5,4} \mathrm{Ab}_{84,1} \mathrm{An}_{10,4}\right)$, whitlockita, cloroapatita, kamacita, taenita (plessita), troilita, cromita, cobre nativo, pentlandita, ilmenita, bravoita, mackinawita e calcopirita. Com base em dados químicos (composição mineral e global) e texturais, o meteorito de Avanhandava é classificado como um condrito $\mathbf{H} 4$.

INTRODUCTION The Avanhandava, State of São Paulo, Brazil, stone meteorite fell in 1952 (lat. $21^{\circ} 27^{\prime} 37^{\prime \prime} \mathrm{S}$; long. $49^{\circ} 57^{\prime} 03^{\prime \prime} \mathrm{W}$ ) and originally weighed about 18 pounds. The stone had a very pronounced polyhedrical shape with its largest dimension having been approximately 16 inches. It produced an almost vertical 40 inches deep impact pit with a uniform diameter of 20 inches. The original mass was broken up and only $9.33 \mathrm{~kg}$ are known to have been preserved.

The meteorite was described by Arid and Rüegg (1965, 1969), who classified it as an olivine-bronzite chondrite, and by Ramdohr (1973) who noted the presence of kamacite, plessite, native cooper, troilite, ilmenite, and chromite. Additional information on this meteorite can be found in Hey (1966), Mason (1967), and Müller and Zähringer (1969). Mason (1967), based on optical determinations, listed a value of $\mathrm{Fa}_{18}$ for the composition of its olivine, and Müller and Zähringer (1969) reported gas retention ages of $\mathrm{U} /{ }^{4} \mathrm{He}=$ $=4.3$ and $\mathrm{K} / \mathrm{Ar}=4.45 \mathrm{~b}$.y. In the present paper, we report the results of a detailed microscopic, electron microprobe, and bulk chemical study of this meteorite and provide additional quantitative data relevant to its classification. This work is part of a systematic study of all Brazilian meteorites which we have in progress.

*On leave from Institut für Mineralogie und Petrographie, Universität Salzburg, A-5020 Salzburg, Áustria

**On leave from Instituto de Geociências, Universidade de São Paulo, Caixa Postal 20899, São Paulo, Brasil 

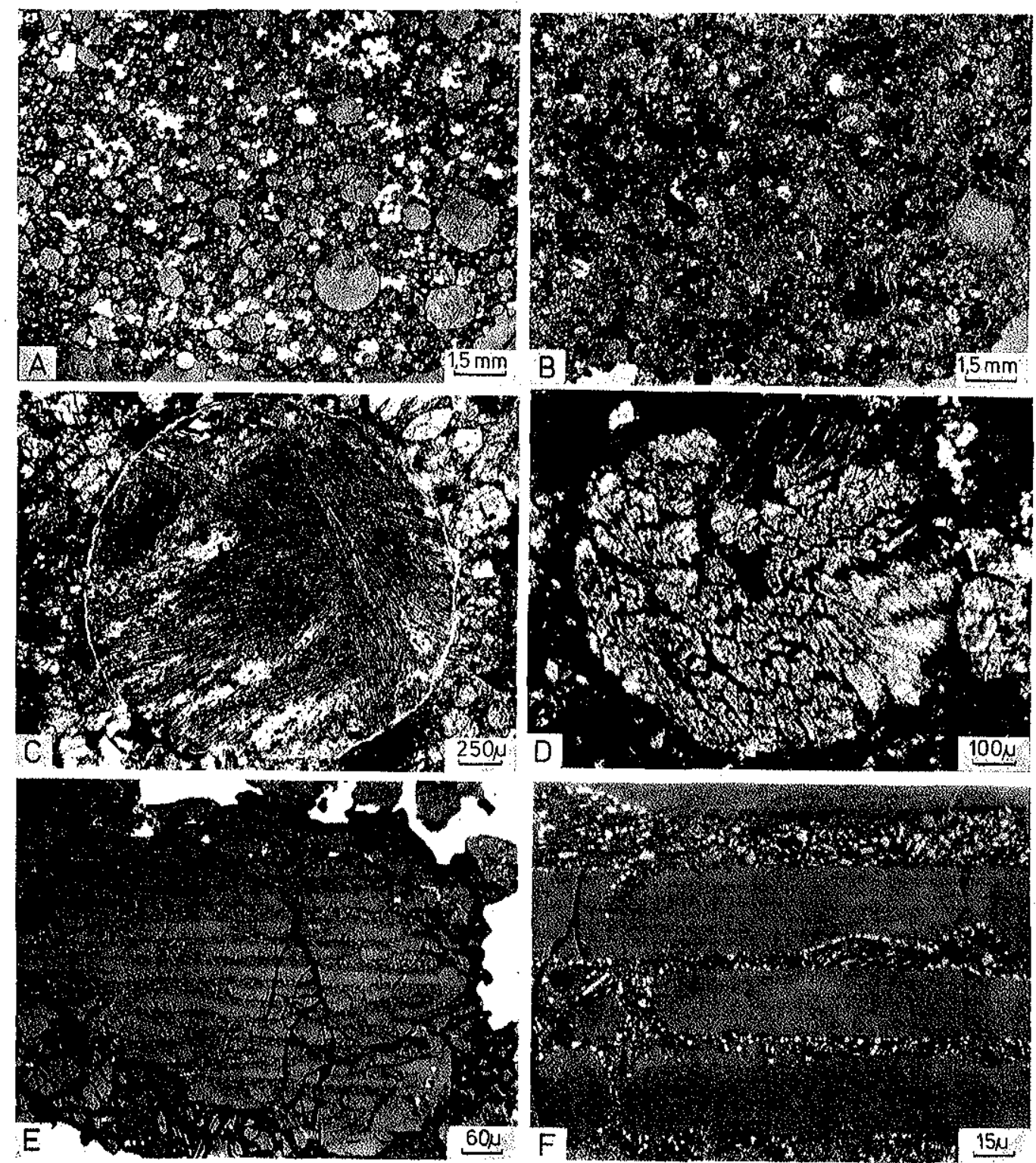

Figure A - Overall texture of the $\mathrm{H} 4$ chondrite Avanhandava, Brazil. Metallic nickel-iron and troilite are white, silicates (olivine, pyroxene) show different shades of gray. Chondritic texture is pronounced. Reflected light

Figure B - Same as Fig. A, but transmitted light and crossed polarizers. Metallic nickel-iron, troilite and glassy material is black; silicates are different shades of gray

Figure $\mathrm{C}-$ Radiating pyroxene chondrule with a thin rim of alkali-rich glass. Black is optically isotropic matrix. Transmitted light, crossed polarizers

Figure D - Pyroxene chondrule showing feathery intergrowth of pyroxene and irregular chondrule outline. Transmitted light, crossed polarizers

Figure $\mathrm{E}-$ - Barred olivine chondrule with irregular outline, consisting of bars of olivine (light gray) and glassy material (dark gray). Tiny, euhedral grains within the glassy material between the olivine bars are decomposition chromite. White is metallic nickel-iron; black are cracks. Reflected light Figure F - Magnified image of Fig. E, showing euhedral decomposition chromite (highest reflectivity), embedded in glassy material (lowest reflectivity) between parallel olivine bars (medium reflectivity) 


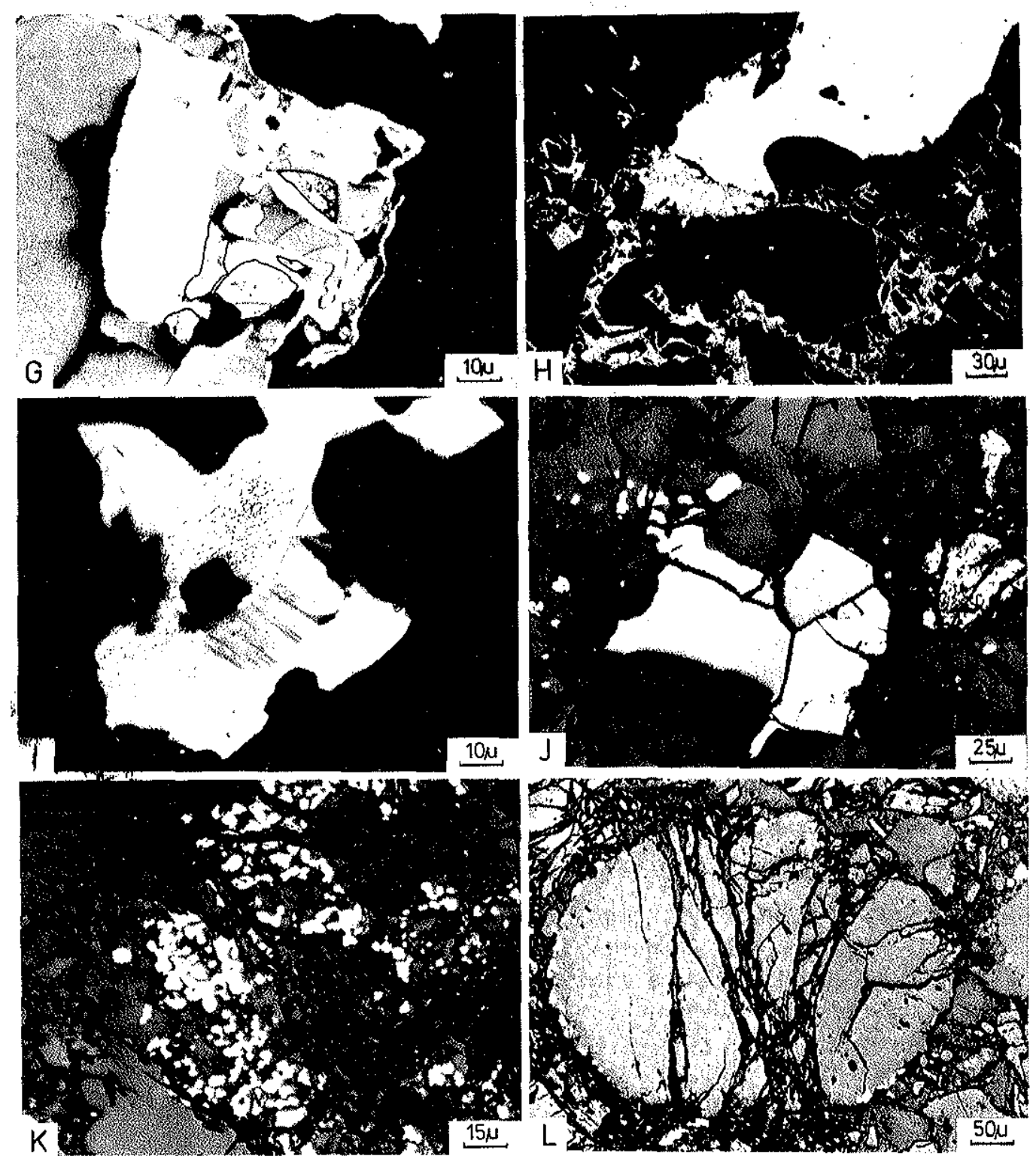

Figure G - Native copper (poor polish, outlined in black), metallic nickel-iron (white, smooth). Gray is troilite. Reflected light

Figure $\mathrm{H}-$ Network-like troilite near the fusion crust, associated with a large grain of kamacite and cutectic troilite-nickel-iron intergrowth. Reflected light

Figure I - Inclusion of pentlandite (white) and mackinawite (gray, cleavage) in troilite (grayish-white). Reflected light

Figure J - Coarse chromite (center, light gray) and aggregate chromite (right, light gray), in paragenesis with silicates (olivine, pyroxene; different shades of dark gray), and troilite (highest reflectivity). Coarse chromite is distinctly euhedral against troilite, but shows curvy contours towards silicates. Black are cracks. Reflected light

Figure K - Aggregate chromite (gray) in tiny crystals within silicates. Reflected light

Figure L - Ghondrule chromite, in a narrow rim of tiny crystals at the outermost margins of a chondrule. Silicates are gray; cracks are black. Reflected light 
ANALYTICAL Procedures The Avanhandava meteorite was examined microscopically in transmitted and reflected light, and by electron microprobe. Compositional data for the minerals listed in Tables I through III were obtained using an Applied Research Laboratories EMX-SM instrument. Analytical conditions were: accelerating potential $15 \mathrm{keV}$, specimen current approximately $0.02 \mu \mathrm{A}$, integration time on scalers $10 \mathrm{sec}$, and spot size 1-2 $\mu \mathrm{m}$ in diameter. Corrections were made for instrumental drift, background, and matrix effects using the correction procedures of Bence and Albee (1968). The standards used are analyzed minerals, i.e., olivine (Marjallahti), augite (\# A-209), andesine (\# AC-362), chromite (\# C53IN8), and apatite.

The bulk chemical analysis of the meteorite was made using the method described by Jarosewich (1966).

TEXTURE The texture of the meteorite is pronounced chondritic, with chondrules ranging in size from about $0.1-2 \mathrm{~mm}$. Chondrule-matrix boundaries are sharp and well-defined (Figs. A and B). The internal textures of the chondrules vary considerably. The most common types are radiating pyroxene chondrules (Fig. C); porphyritic chondrules with subhedral to euhedral crystals of olivine and pyroxene in a microscrystalline matrix; barred olivine chondrules (Figs. E and F); and glassy chondrules, with turbid and mostly slightly birefringent glass. Chondrule fragments are common, and the matrix between chondrules is transparent and microcrystalline. A major constituent is turbid igneous glass. Evidence of recrystallization is shown by the grayish, fine-grained, non-opaque interstitial matrix of the meteorite (optically unresolvable), and by microcrystalline to fibrous interstitial material within chondrules. Frequently, skeletal and feathery crystals are noted, both in chondrules (Fig. D) and in the matrix.

MINERALOGY Olivine $\left(\mathrm{Fa}_{17.3}\right)$ and low-Ca pyroxene $\left(\mathrm{Fs}_{16.5}\right)$, a bronzite, are the most common constituents of the chondrite. These values are consistent with an $\mathbf{H}$-group classification according to Keil and Fredriksson (1964). Both are uniform in composition (Table $\mathrm{I}$ ), the mean deviation values in $\mathrm{Fe} / \mathrm{Fe}+\mathrm{Mg}$ are, respectively, $2.3 \%$ and $: 5.2 \%$. Low-Ca pyroxene occurs both as untwinned orthopyroxene and as polysynthetically twinned clinopyroxene, with an inclined maximum extinction of $29^{\circ}$ against c. Electron microprobe traverses across twinned and untwinned pyroxene grains do not indicate any compositional variations.

Calcic pyroxene (diopside) $\left(\mathrm{Wo}_{45.3} \mathrm{En}_{49.0} \mathrm{Fs}_{5.7}\right)$ occurs in finely dispersed crystallites of a few microns in diameter throughout the meteorite (Table I), amounting to approximately $18 \%$ of the total pyroxene content.

Plagioclase (oligoclase), averaging, $\mathrm{Or}_{5 \cdot 4} \mathrm{Ab}_{84 \cdot 1} \mathrm{An}_{10 \cdot 4}$ in composition (Table I), is present in small grains (4-6 $\mu \mathrm{m})$ and is difficult to recognize in the microscope. It is commonly associated with calcic pyroxene and mostly confined to the interchondrule matrix.

Whitlockite is an accessory phase and occurs in large grains of occasionally $600 \times 200 \mu \mathrm{m}$ in size, although most range between 20 to $40 \mu \mathrm{m}$. Microprobe analyses (Table II) indicate compositional homogeneity.

Chlorapatite (Table II) is another accessory phase but is less abundant than whitlockite. It occurs in irregular grains $8 \times 10$ to $12 \times 16 \mu \mathrm{m}$ in size and is always lacking euhedral crystal form. 
Table I - Electron microprobe analyses (in wt. \%) and structural formulae of olivine, low-Ca pyroxene, calcic pyroxene, and feldspar from the Avanhandava, Brazil, Chondrite

\begin{tabular}{|c|c|c|c|c|}
\hline & $\begin{array}{l}\text { Oivine } \\
(100)^{*}\end{array}$ & $\begin{array}{l}\text { Low-Ca } \\
\text { pyroxene } \\
(100)^{\star} .\end{array}$ & $\begin{array}{c}\text { Calcic } \\
\text { pyroxene } \\
(80)^{*}\end{array}$ & $\begin{array}{l}\text { Plagioclase } \\
(80)^{*}\end{array}$ \\
\hline $\mathrm{SiO}_{2}$ & 40.1 & 56.1 & 54.2 & 64.7 \\
\hline $\mathrm{T}_{2} \mathrm{O}_{2}$ & 0.04 & 0.12 & 0.43 & n.d. \\
\hline $\mathrm{Al}_{2} \overrightarrow{\mathrm{O}}_{3}$ & 0.05 & 0.13 & 0.68 & 20.8 \\
\hline $\mathrm{Cr}_{2} \mathrm{O}_{3}$ & 0.02 & 0.09 & 0.69 & n.d. \\
\hline $\mathrm{FeO}$ & 16.2 & 11.2 & 3.6 & 0.68 \\
\hline Mno & 0.42 & 0.46 & 0.22 & n.d. \\
\hline Mg0 & 43.5 & 30.9 & 17.3 & 0.26 \\
\hline $\mathrm{CaO}$ & 0.06 & 0.68 & 22.3 & 2.2 \\
\hline $\mathrm{Na}_{2} \mathrm{O}$ & 0.01 & 0.04 & 0.63 & 9.9 \\
\hline $\mathrm{K}_{2}{ }^{0}$ & n.d. & n.d. & n.d. & 0.97 \\
\hline TOTAL & 100.39 & 99.72 & 100.05 & 99.51 \\
\hline \multicolumn{5}{|c|}{ Number of ions on the basis of: } \\
\hline & $0=4$ & $0=6$ & $0=6$ & $0=32$ \\
\hline$\$ 1$ & 1.008 & 1.988 & 1.976 & 11.542 \\
\hline A1 & 0.001 & 0.005 & 0.029 & 4.360 \\
\hline $\mathrm{Ti}$ & 0.001 & 0.003 & 0.012 & - \\
\hline $\mathrm{Cr}^{2+}$ & -- & 0.003 & 0.020 & -- \\
\hline $\mathrm{Fe}$ & 0.341 & 0.333 & 0.110 & 0.101 \\
\hline Mn & 0.009 & 0.014 & 0.007 & -- \\
\hline $\mathrm{Mg}$ & 1.630 & 1.632 & 0.941 & 0.069 \\
\hline $\mathrm{Ca}$ & 0.002 & 0.026 & 0.871 & 0.424 \\
\hline $\mathrm{Na}$ & -- & 0.003 & 0.045 & 3.414 \\
\hline K & -- & -- & -- & 0.221 \\
\hline$Z$ & 1.009 & 1.993 & 2.005 & 15.884 \\
\hline$X Y$ & 1.983 & 2.014 & 2.006 & 4.229 \\
\hline$X Y Z$ & 2.992 & 4.007 & 4.011 & 20.113 \\
\hline \multirow[t]{3}{*}{. } & $\mathrm{Fa} 17.3$ & Fs 16.5 & Fs $\quad 5.7$ & Ab 84.1 \\
\hline & Fo 82.7 & En 82.0 & En 49.0 & An 10.4 \\
\hline & & Wo 1.3 & Wo 45.3 & or $\quad 5.4$ \\
\hline
\end{tabular}

Among the opaque minerals are kamacite, taenite (plessite), native copper, chromite, troilite and ilmenite which have previously been noted in this meteorite by Ramdohr (1973), as well as pentlandite, bravoite, mackinawite, and chalcopyrrhotite. 
Table II - Electron microprobe analyses (in wt. \%) of whitlockite and chlorapatite from the $\Lambda$ vanhandava, Brazil, chondrite (averages of 50 and 35 point analyses, respectively)

WhitTockite

0.42

0.02

0.61

0.01

3.9

46.0

$\mathrm{CaO}$

$\mathrm{Na}_{2} \mathrm{O}$

$\mathrm{P}_{2} \mathrm{O}_{5}$

F

Cl

Total
45.8

n.d.

n.d.

99.46
Chlorapatite

0.09

n.d.

0.42

0.01

0.17

53.9

0.27

41.8

0.6

4.9

102.16

Minus $0 \equiv F, C 11.36$

Total $\quad 100.80$

Kamacite and taenite are major constituents of the meteorite and are present in irregular, sometimes globule-like grains. Kamacite grains vary markedly in size but are generally larger than taenite grains and both are often intergrown.

Native copper is found as irregular grains $(2 \times 2$ to $5 \times 5 \mu \mathrm{m})$ in taenite (Fig. G), occasionally associated with coarse troilite and rarely bordering it.

Troilite is a major opaque, next to metallic nickel-iron, and occurs in large grains. Near the fusion crust, troilite was mobilized and forms network-like aggregates (Fig. $\mathrm{H}$ ).

Pentlandite shows several modes of occurrence, namely, as isolated, somewhat rounded grains, widely distributed, especially near network-like troilite; in form of tiny, irregularly shaped grains in troilite (Fig. I), which probably formed by exsolution; and as weathering product, either as thin layers rimming troilite or penetrating it along cracks. The latter two modes of occurrence are observed most frequently. Relatively large grains of pentlandite $(10 \times 20 \mu \mathrm{m})$ exhibiting distinct cleavage along (111) are more restricted to random sections of troilite. Very rarely, transformation into fingered bravoite, proceeding from grain boundaries toward the interior, is detected.

Mackinawite, a mineral with properties similar to valleriite, but quite different in structure and composition, occurs commonly as an exsolution product of pentlandite and is readily recognizable by its strong anisotropism. It also occurs as slightly rounded grains with 
distinct cleavage, as inclusions in troilite, sometimes intergrown with chalcopyrrhotite. Most probably mackinawite is a breakdown product of chalcopyrrhotite.

Chromite varies greatly in its type of occurrence. The following types were found (nomenclature after Ramdohr, 1973): coarse chromite; aggregate chromite; decomposition chromite; exsolution chromite; and chondrule chromite. The most abundant types are coarse, aggregate, and chondrule chromite, whereas decomposition and exsolution chromite are rare.

Coarse chromite occurs in relatively larger $(15 \times 20 \mu \mathrm{m}$ and greater) grains (Fig. J), which are found in the matrix, either surrounded by silicates or bordering against troilite and/or metallic nickel-iron. They are always xenomorphic against silicates, but idiomorphic against the troilite and nickel-iron. Fractured chromite grains are often penetrated by troilite. This chromite is very uniform in composition from grain to grain, and no zoning occurs (Table III), and its composition is in agreement with that of $\mathbf{H}$ group chondrites (Bunch et al., 1967).

Aggregate chromite occurs as closely clustered aggregates of mostly rounded grains and unoriented crystals of considerably smaller size than the coarse chromite. The grains often are in contact with each other and form larger agglomerations (Figs. $\mathrm{J}$ and $\mathrm{K}$ ). It is interesting to note that these grain clusters are restricted to somewhat angular silicate (olivine) fragments and show transition to myrmekitic intergrowth with olivine and/or pyroxene.

Decomposition chromite is restricted to a few barred olivine chondrules. Minute chromite grains $1 \mu \mathrm{m}$ and considerably less in size occur along the grain boundaries of olivine (Figs. E and F). Formation of these minute grains can be explained by unmixing of either a Cr-rich silicate or a Cr-rich glass. The occurrence of this chromite in glassy material in chondrules (Figs. $\mathbf{E}$ and F) suggests, however, that unmixing of a glass is the more likely mode.

Exsolution chromite is rare and occurs as a fine dust, dispersed in some pyroxene chondrules. Chondrule chromite (Fig. L) was observed in a few chondrules. It occurs either as large euhedral to subhedral grains in the centers of the chondrules or it is confined to their outermost margins. Chondrule chromite sometimes has very small, lath-like, exsolved ilmenite. Compositionally, chondrule chromite has somewhat higher $\mathrm{Mg}$ and $\mathrm{Ti}$ contents than coarse chromite.

BULK GHEMICAL COMPOSITION Chemical data and CIPW molecular values for the Avanhandava meteorite are listed in Table IV, which also contains for comparison a chemical analysis of the meteorite by Arid and Rüegg (1969). The analyses are generally in good agreement and are consistent with an $\mathrm{H}$-group classification of the meteorite according to Keil (1969). The calculated $\mathrm{Fe} / \mathrm{SiO}_{2}$ and $\mathrm{Fe} / \mathrm{Fe}$ ratios $(0.74$ and 0.59 , respectively) also agree well with such classification. Van Schmus and Wood's (1967) averages for the H-group chondrites are 0.77 and 0.63 , respectively. Additional evidence for the $\mathrm{H}$-group classification of the chondrite stems from the total $\mathrm{Fe}$ content, $27.15 \%$, which is close to the value listed by Keil and Fredriksson (1964), $27.52 \%$, for the $\mathrm{H}$-group chondrites.

The GIPW molecular norm shows olivine, orthopyroxene, and nickel-iron as major constituents; plagioclase, clinopyroxene, and troilite occur in minor amounts whereas chromite, ilmenite, and apatite make up the accessory phases.

CONClusions Based on mineral compositions, particularly the $\mathrm{Fa}$ and $\mathrm{Fs}$ contents of olivines and orthopyroxenes; the abundance of metallic phases; and the bulk chemical 
Table III - Electron microprobe analyses (in wt. \%), structural formulae, and molecular end members for coarse and chondrule chromite from the Avanhandava, Brazil, chondrite. Averages of 100 point analyses each

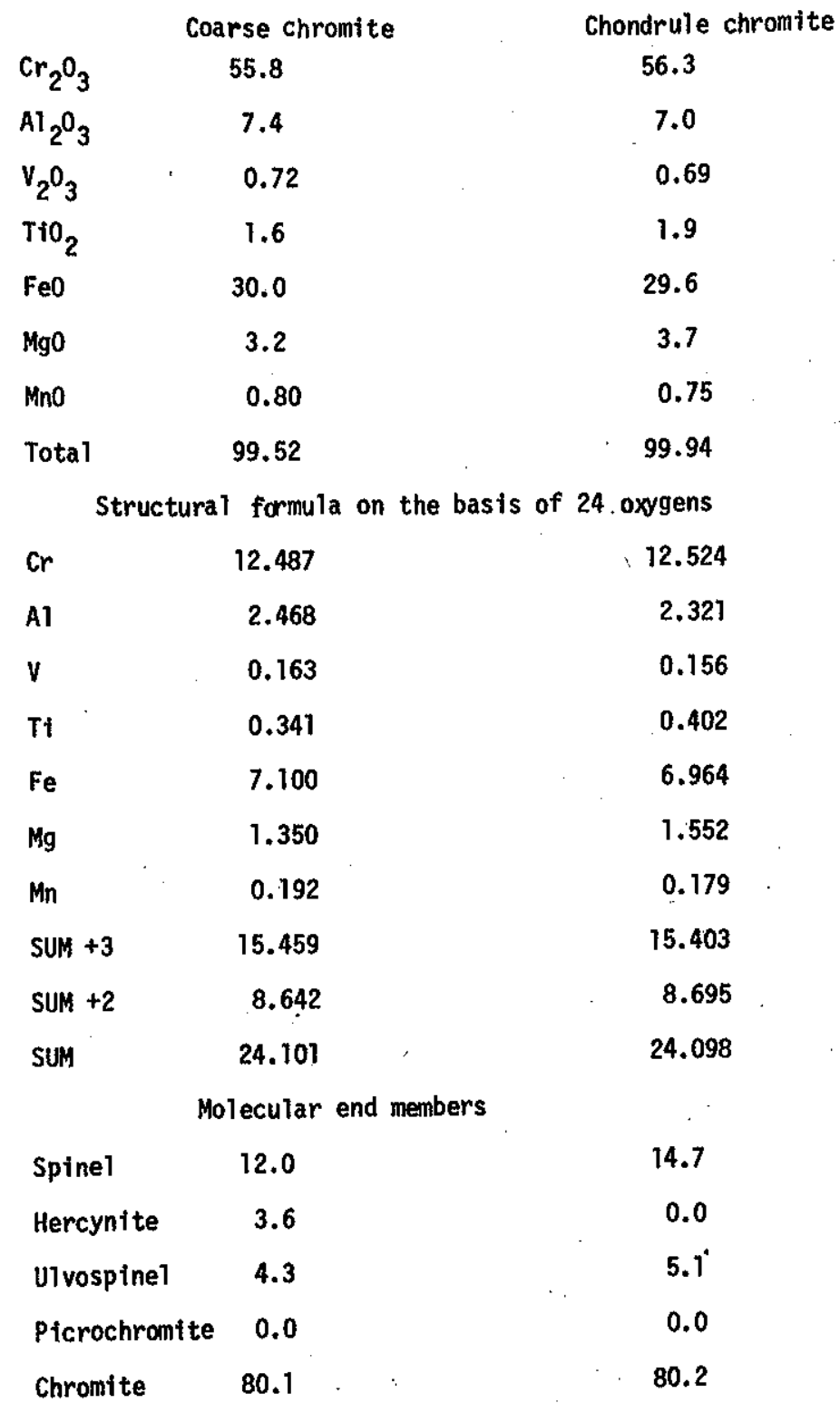

composition, particularly the $\mathrm{Fe} / \mathrm{SiO}_{2}, \mathrm{Fe} / \mathrm{Fe}$, and $\mathrm{SiO}_{2} / \mathrm{MgO}$ ratios as well as the total $\mathrm{Fe}$ content, the Avanhandava meteorite is classified as an $\mathrm{H}$-group or olivine-bronzite chondrite. Additional features, which include the relatively uniform composition of olivines and orthopyroxenes (mean standard deviation less than $5 \%$ ); presence of igneous glass; abundant monoclinic pyroxene; and the occurrence of well-defined chondrules, are indicative that the meteorite can be placed into the petrologic class 4 of Van Schmus and Wood (1967). 
Table IV - Ghemical analyses and GIPW norm of the Avanhandava chondrite

\begin{tabular}{|c|c|c|c|c|c|}
\hline $\mathrm{SiO}_{2}$ & $\begin{array}{c}1 \\
36.65\end{array}$ & $\begin{array}{c}2^{*} \\
36.70\end{array}$ & \multirow{2}{*}{ Olivine } & $\begin{array}{l}\text { sis } \\
\text { Fo }\end{array}$ & $\begin{array}{l}1 \\
24.81\end{array}$ \\
\hline $\mathrm{TiO}_{2}$ & 0.12 & 0.05 & & Fa & 8.64 \\
\hline $\mathrm{Al}_{2}{ }^{\mathrm{O}}{ }_{3}$ & 2.10 & 3.50 & Hvmersthene & I En & 21.50 \\
\hline $\mathrm{Cr}_{2} \mathrm{O}_{3}$ & 0.48 & $\operatorname{tr}$ & 2x) & Fis & 6.79 \\
\hline $\mathrm{Fe} 0$ & 9.95 & 10.21 & & Wo & 2.03 \\
\hline Mno & 0.33 & 0.24 & Diopside & En & 1.41 \\
\hline $\mathrm{MgO}$ & 23.21 & 24.80 & & Fs & 0.44 \\
\hline $\mathrm{Ca} 0$ & 1.68 & 2.32 & & $\mathrm{Ab}$ & 6.66 \\
\hline $\mathrm{Na}_{2} \mathrm{O}$ & 0.78 & 0.77 & Plagioclase & An & 1.99 \\
\hline $\mathrm{K}_{2} \mathrm{O}$ & 0.09 & 0.20 & & $10 x$ & 0.53 \\
\hline $\mathrm{P}_{2} \mathrm{O}_{5}$ & 0.26 & 0.30 & Whitlockite & & 0.58 \\
\hline $\mathrm{H}_{2}{ }^{0+}$ & 0.38 & & Chromite & & 0.72 \\
\hline $\mathrm{H}_{2} \mathrm{O}^{-}$ & 0.09 & & Ilmenite & & 0.23 \\
\hline $\mathrm{Fe}$ & 15.96 & 15.15 & Nicke1-iron & & 18.19 \\
\hline $\mathrm{Ni}$ & 1.99 & 1.73 & Troilite & & 5,48 \\
\hline Co & 0.08 & nd & & & \\
\hline FeS & 5.43 & 6.11 & & & \\
\hline C & 0.04 & & & & \\
\hline TOTAL & 99.62 & 102.08 & & & \\
\hline Total Fe & 27.15 & 27.3 & & & \\
\hline
\end{tabular}

Acknowledgments We are grateful to Dr. Fahad M. Arid, of the Faculdade de Filosofia, Ciências e Letras de São José do Rio Preto, Brazil, for making the meteorite available for study. This work is supported in part by a Fulbright-Hays Travel Grant to W. Paar; a travel grant by Fundação de Amparo à Pesquisa do Estado de São Paulo (Geologia 707/1975) to C. B. Gomes; and by the National Aeronautics and Space Administration, Grant NGL 32-004-064 (K. Keil, Principal Investigator).

\section{REFERENCES}

ARID, F. M., and RÜEGG, N. R. - 1965 - Nota preliminar sobre um meteorito de Avanhandava, SP. Ciência e Cultura 17(2): 128

ARID, F. M., and RÜEGG, N. R. - 1969 - Meteorito de Avanhandava, SP. An. Acad. Bras. Ci. 41(2): $155-160$

BENGE, A. E., and ALBEE, A. L. - 1968 - Empirical correction factors for the electron microanalysis of silicates and oxides. J. Geol. 76: $382-403$ 
BUNCH, T. E., KEIL, K., and SNETSINGER, K. G. - 1967 - Chromite composition in relation to chemistry and texture of ordinary chondrites. Geochim. Cosmochim. Acta 31: 1 569-1 582 HEY, M, H. - 1966 - Catalogue of Meteorites. British Museum, 3. ed., London.

JAROSEWICH, E. - 1966 - Chemical analyses of ten stony meteorites. Geochim. Cosmochim. Acta 30: $1261-1265$

KEIL, K. - 1969 - Meteorite composition. In: Wedepohl, K. H. (Ed.), Handbook of Geochemistry, Vol. I, pp. 78-115, Springer-Verlag

KEIL, K., and FREDRIKSSON, K. - 1964 - The iron, magnesium, and calcium distribution in coexisting olivines and rhombic pyroxenes of chondrites. J. Geophys. Res. 69: 3 487-3 51:5.

MASON, B. - 1963 - Olivine composition in chondrites - a supplement. Geochim. Cosmochim. Acta 31: 1 100-1 103

MÜLLER, H. W., and ZÄHRINGER, J. - 1969 - Rare gases in stony meteorites. In: Millman, P. M. (ed.), Meteorite Research, pp. 845-856. D. Reidel

RAMDOHR, P. - 1973 - The opaque minerals in stony meteorites. Akademie-Verlag, Berlin

VAN SGHMUS, W. R., and WOOD, J.A. - 1967 - A chemical-petrologic classification for the chondritic meteorites. Geochim. Cosmochim. Acta 31: 747.765 